\title{
Linguistic Contradiction: Power and Politeness in Courtroom Discourse ${ }^{1}$
}

\author{
Linda Sanderson \\ University of Waterloo
}

This article examines the courtroom as a workplace using Brown and Levinson's politeness model. It is argued that while the model is a valuable tool for analyzing courtroom discourse, the courtroom, as well as institutional and organizational contexts in general, possesses characteristics that demand a more complex contextual analysis. The article first looks at some of the distinct characteristics of language use in a courtroom setting, and then analyzes excerpts drawn from a courtroom transcript. Institutional factors that affect the model's performance in this workplace are delineated. The article concludes that these institutional factors are not unique to the courtroom; they are relevant to understanding language use in many types of workplace, including corporate, public, and organizational contexts.

CONSIDERING THE PURPOSES OF THE LEGAL SYSTEM - to use language efficiently and logically to arrive at the truth - one might propose that Grice's oft-cited Cooperative Principle and its supporting Maxims were a model for courtroom discourse: Speak the truth. Be relevant. Avoid ambiguity and obscurity. Say just what is required. Or, in the more eloquent version of the Cooperative Principle: "Make your conversational contribution such as is required, at the stage at which it occurs, by the accepted purpose or direction of the talk exchange in which you are engaged" (Grice, 1975, p. 45). Grice proposed that the Cooperative Principle and the Maxims underlay all talk-exchanges and that all conversations were based on an implicit presumption of cooperation.

Many legal evidentiary rules are, indeed, congruent with Grice's four Maxims, but, like Grice's Cooperative Principle, legal rules are often honoured more in their breach than in their observance. The court's rules were developed to achieve an environment which is rational and efficient, 
but deviations from that ideal regularly occur (Penman, 1987a). Penman suggested that such deviations could be explained by the politeness model of Penelope Brown and Stephen C. Levinson (1987), which is based on Erving Goffman's (1967) concept of "face." Brown and Levinson assume that Grice's Cooperative Principle always remains in operation, but argue that polite behaviour deviates from Grice's logical presuppositions for the purpose of observing "face," and that it is the very deviation that communicates by inference the politeness message. Thus, Penman argued that "while informational goals may appear to be the sine qua non of courtroom communication, there is more to discourse than this. There are additional goal orientations best described by the concept of facework" (Penman, 1990, p. 17).

While Penman's proposal to use Brown and Levinson's politeness model to analyze face concerns in the courtroom seems reasonable, little research has been published on the application of the model to courtroom discourse, despite increasing interest in courtroom talk in recent years. ${ }^{2}$ Of import to this paper is a study by Cashion (1985) which revealed that the politeness strategies selected by courtroom speakers in fact did not fulfill the expectations of Brown and Levinson's politeness model: those with the most power, the judges, did not use the least politeness, as the model would have predicted; and those with the least power, the witnesses, did not use the most. ${ }^{3}$ This surprising result raises interesting questions: were these particular results an aberration which another study of a different courtroom might not support? Or, does a courtroom context contain factors which affect the functioning of the purportedly universal politeness model? Certainly, the courtroom presents a somewhat anomalous speech situation in comparison with casual conversation. Indeed, distinct differences have been identified in recent years between the structure of discourse in everyday social interaction and in institutional contexts such as a courtroom (e.g. Atkinson and Drew, 1979; Fisher, 1984; Penman, 1987a), differences which Penman (1987a) has attributed to "the impact of institutional authority" (pp. 204-5).

The purpose of this paper is to apply the politeness model in a workplace context such as the courtroom, and to describe the institutional factors affecting its performance there. I first examine aspects of language in the legal context which distinguish it from everyday conversation. Secondly, I review Brown and Levinson's politeness model and test its operation in actual courtroom discourse, using as samples for my brief study 
the speech of institutional representatives - a judge and a lawyer. Finally, I discuss additional factors which are present in institutional contexts and which must be considered in the selection and analysis of politeness strategies. It is my position that while Brown and Levinson's politeness model plays a significant role in analyses of courtroom discourse, the legal site - and, indeed, all institutional and organizational workplaces possesses characteristics that demand a more complex contextual analysis.

\section{Courtroom Discourse}

Courtroom "conversation" differs in many ways from ordinary conversation, the result of the institutional nature of its context. First of all, unlike most conversation, the format of courtroom conversation is generally the question-answer adjacency pair. Secondly, the type of speaker turn is fixed to the acting role - only the lawyer or the judge has the right to ask questions (Atkinson and Drew, 1979). Closed questions are generally used, and the witness is "under strong obligatory pressure to answer and to answer in certain ways only" (Penman, 1987a, p. 214). The ordinary processes of relationship and identity management which include "the freedom to negotiate the right to speak, to qualify what is said, to demand respect [and] to distance or withdraw, if necessary, to save face" are prohibited, at least as far as witnesses are concerned (Penman, 1987b, p. 16). These characteristics result in discourse which is "highly formalized and atypical... an extreme in conversational types" (Penman, 1987a, p. 217).

Yet another aspect of conversation in the courtroom is its "double frame" of listeners. For example, the main business of the courts, which is examination and cross-examination of witnesses, is attended to by a set of listeners beyond the immediate speaker and hearer in the persons of others present in the courtroom - the judge, possibly the jury, the courtroom staff, and so on. While legal conversation is designed to serve a functional purpose for these second-level listeners, they rarely play an active role in the conversation. ${ }^{4}$

Finally, the backbone of this highly controlled discourse structure lies in the institutional authority of the court which serves to bring about these conversations: for example, a subpoena compels a witness' attendance under threat of imprisonment, and a rigid power hierarchy prevails within the courtroom. The significance of this complex of power and control factors lies in its ultimate impact; as Penman has observed, "the talk-exchanges in court...appear to be other than a genuinely cooperative effort. A 
contradiction, in fact, appears to exist; viz., that courts need to coerce participants to be cooperative" (1987a, p. 214).

\section{Brown and Levinson's Politeness Model}

This pronounced presence of authority in the courtroom creates an inherent threat to what Brown and Levinson (1987) refer to as "face." They define face as "the public self-image that every member wants to claim for himself" (p. 61), and they break it down into negative face - the basic claim "to freedom of action and freedom from imposition" - and positive face - "the want of every member that his wants be desirable to at least some others" (pp. 61-2). Acts which by their nature contravene face wants are labelled "face-threatening acts" or FTAs (p. 65). Within the courtroom context, face can be threatened, for example, in cross-examination should a lawyer challenge or contradict a witness' testimony. Alternatively, face can be threatened by the very act of compelling a witness' attendance at court or, equally, in compelling his or her testimony. In light of the fact that the evidence-gathering process is largely question and answer, that failure to appear in court or to answer questions can subject a party to significant penalties, and that, ultimately, the judge must reach decisions which favour one side or the other, the courtroom can rightfully be viewed as a site of substantial threat to both negative and positive face.

In order to handle face-threatening situations appropriately, Brown and Levinson propose that speakers must first weigh their seriousness by considering three factors - the social distance between the speaker and the hearer $(D)$, their relative power $(P)$, and the degree to which the facethreatening act is rated an imposition in that culture (R) (pp. 76-7). Brown and Levinson then claim that the calculated weightiness of the FTA will predict the speaker's selection of one of five main politeness strategies, which include:

1. Doing the FTA baldly, on record without redressive action,

2. choosing positive politeness,

3. choosing negative politeness,

4. doing the FTA off record, and, finally,

5. avoiding doing the FTA. (p. 69)

Each of the strategies employs a successively greater degree of what Brown and Levinson call "redress" - action which attempts to counter-act potential face damage by doing it in such a way as to indicate that no threat is intended (p. 70). Strategies 2, 3, and 4-negative politeness, positive 


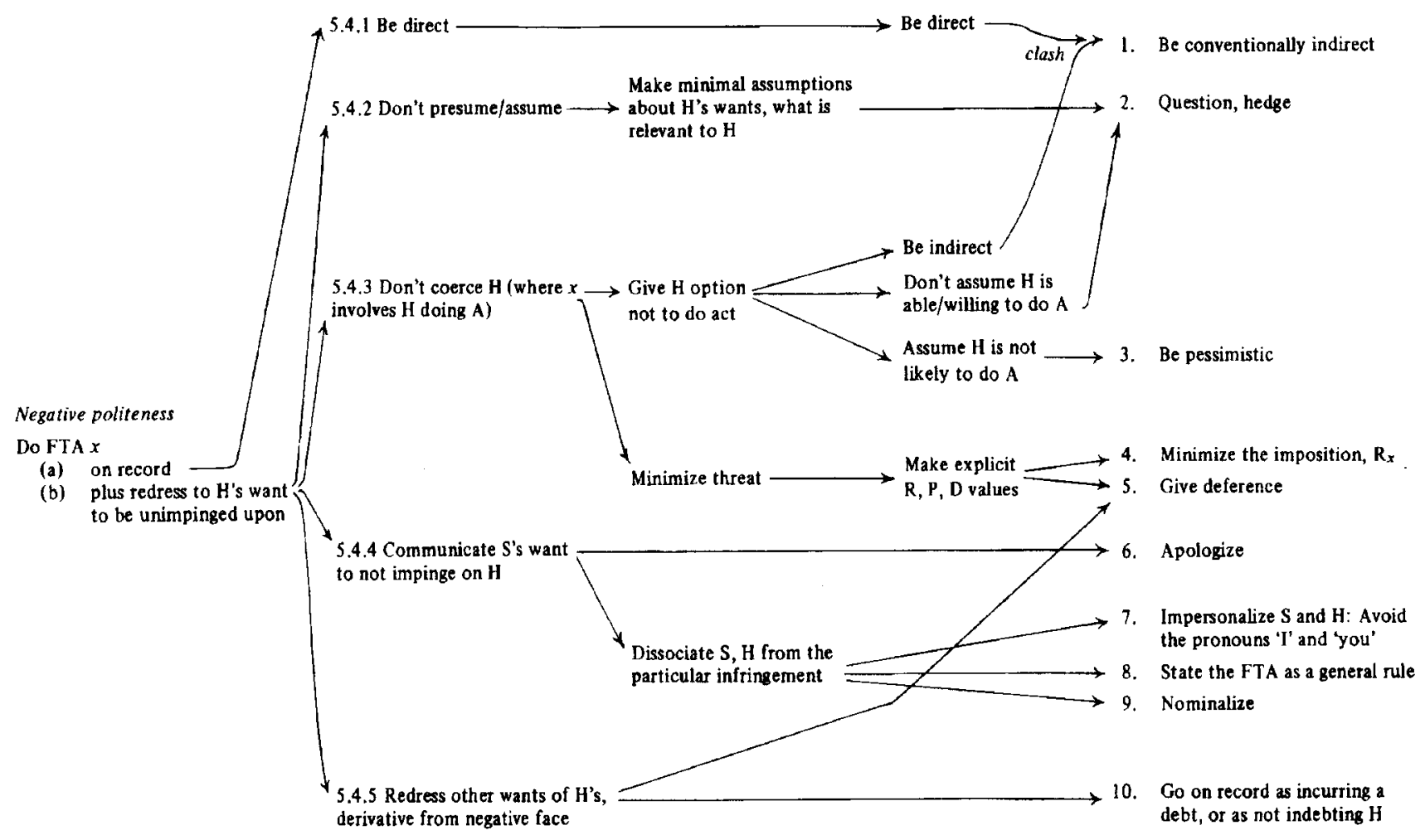

Figure 1. Chart of Strategies: Negative Politeness. From P. Brown and S.C. Levinson (1987). Politeness: Some Universals in Language Usage, p. 131. Cambridge: Cambridge University Press. (C) Cambridge University Press, 1978, 1987. Reprinted with permission. 


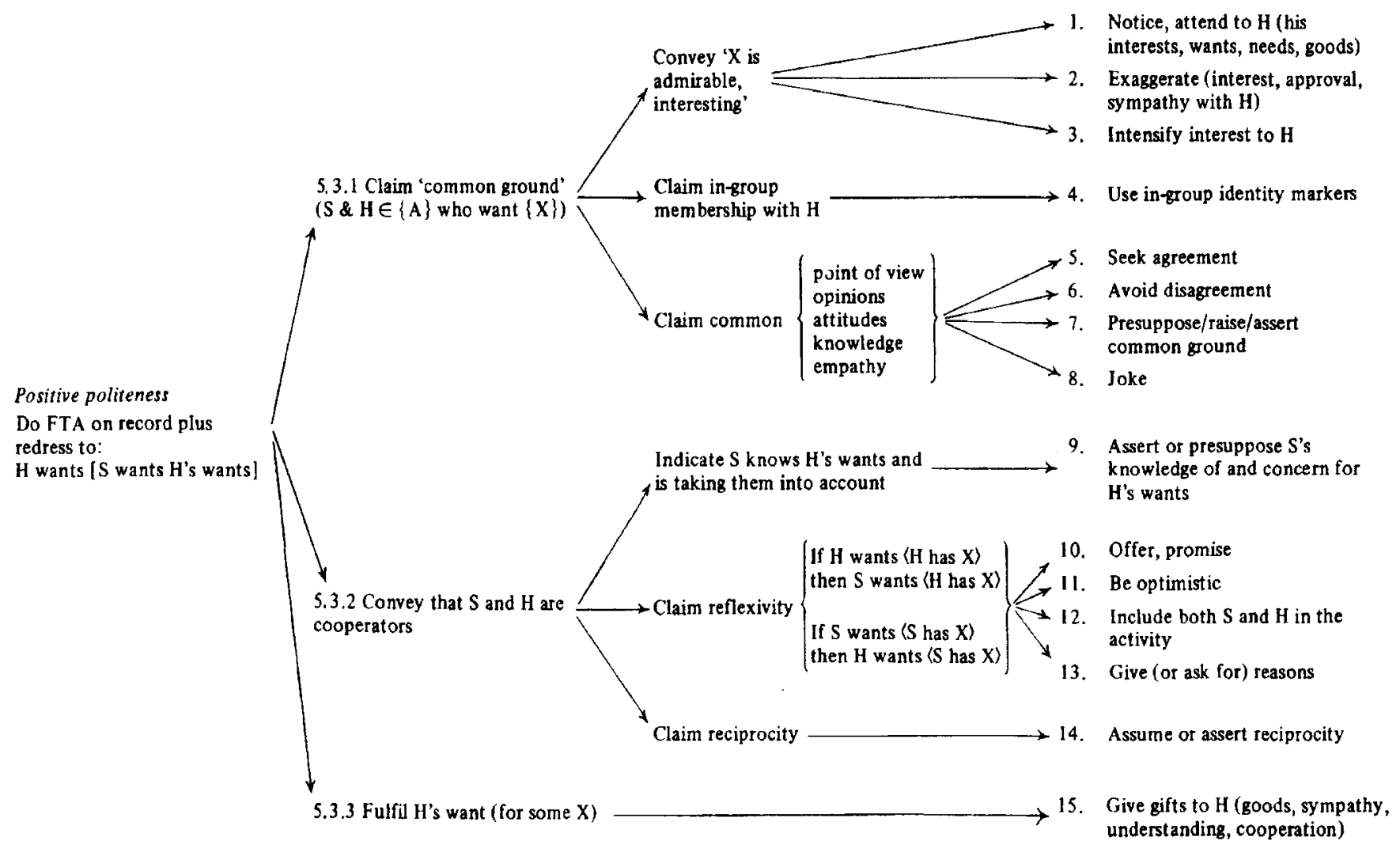

Figure 2. Chart of Strategies: Positive Politeness. From P. Brown and S.C. Levinson (1987). Politeness: Some Universals in Language Usage, p. 102. Cambridge: Cambridge University Press. C Cambridge University Press, 1978, 1987. Reprinted with permission. 


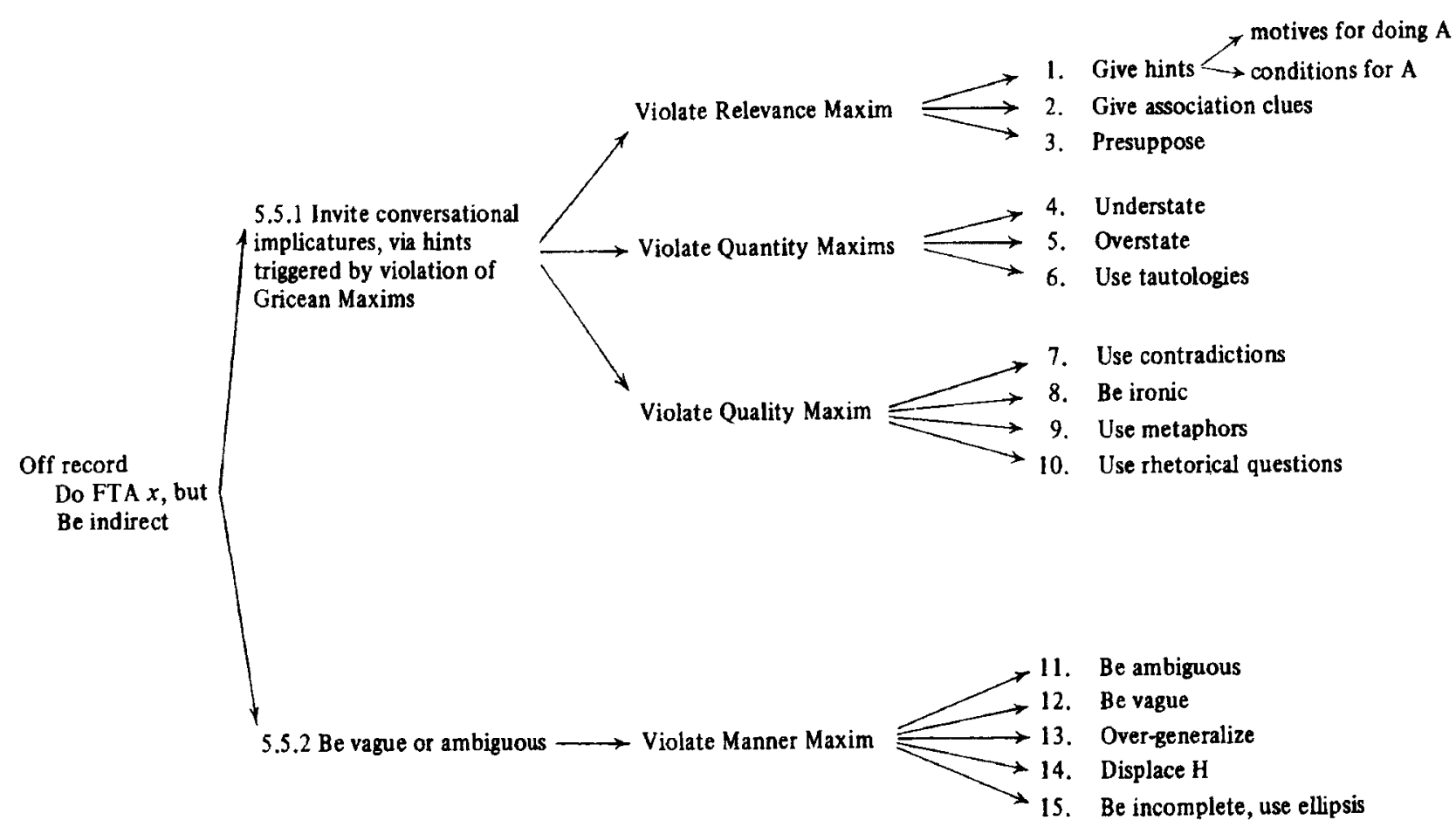

Figure 3. Chart of Strategies: Off Record. From P. Brown and S.C. Levinson (1987). Politeness: Some Universals in Language Usage, p. 214. Cambridge: Cambridge University Press. @ Cambridge University Press, 1978, 1987. Reprinted with permission. 
politeness, and off record, respectively - can be further broken down into inventories of specific sub-strategies, as shown in Figures 1, 2 and 3. In choosing a general strategy and then a specific sub-strategy, a speaker must consider the payoff which can be obtained from the choice together with the weightiness factor of the FTA. As soon as a speaker determines an appropriate mix of payoff and FTA weightiness, he or she will not need to progress further on the strategy list because, as Brown and Levinson point out, "no actor will use a strategy for an FTA that affords more opportunity for face-risk minimization than is actually required to retain [the hearer's] cooperation" (p. 74).

The tremendous institutional power which is uniquely present in legal contexts demands special comment here. Because of the immensity of the court's power, which, as noted above, Penman termed as having a "coercive" effect on the courtroom's linguistic exchanges, extreme power differentials are created between speaking and hearing parties in the courtroom, so that extremely low or extremely high power assessments can result, depending on the addressee. The impact of institutional power therefore proves the key determinant to politeness strategizing in the courtroom.

In light of this factor, we could summarize the operation of the politeness model in the courtroom by predicting that those holding the most power, such as the judge, who are speaking "down" the court's power hierarchy, will choose the least "polite" strategies. The substantial power and authority inherent in legal proceedings, which is symbolically embodied in the judge, outweighs the otherwise heavily-weighted social distance and rank of imposition factors to result in a low FTA weightiness factor, regardless of the judge's addressee. Those holding the least power, such as the witnesses, who are speaking "up" the court's power hierarchy, will choose the most "polite" strategies. The witness' position at the bottom of the court's power hierarchy, with consequent inability to exercise control over either the judge or the lawyers, would result in a heavily-weighted power factor, suggesting a high-numbered politeness strategy in all circumstances. Thus the judge would use "bald on record without redress" language — language which would meet the specifications of Grice's maxims by being clear, direct, unambiguous, and concise - and the witness would choose either not to do the FTA, to do it off record, or, perhaps, to do it with negative politeness - thereby deviating from Grice's Cooperative Principle so as to infer politeness. (Of course, the fact that the witness is significantly constrained by the atypical characteristics of legal "conversation" may affect 
his or her selections.) The strategies chosen by lawyers, who rank between the other two parties on the power hierarchy, should vary between more and less polite strategies according to the addressee. In speaking to witnesses, the lawyer's restrictive questioning style and the witness' inability to exercise control at the lawyer's expense would lead to a low-weighted power factor for the lawyer, while in speaking to the judge, the reverse ability to exercise control would lead to a heavily-weighted power factor. Overall, then, one might expect a lawyer to adopt a low-numbered strategy opposite witnesses, and a higher-numbered strategy opposite the judge.

\section{Application}

Having made general predictions based on the politeness model as to the politeness strategies which will be selected in the courtroom, I will now apply the model to actual trial discourse. ${ }^{5}$ In the interests of brevity, I shall focus only on the discourse of a judge and a lawyer in their interactions with witnesses.

\section{Judge-Witness Interaction}

The five excerpts below are taken from a court transcript of a trial of an attempted murder charge which was held in Vancouver, B.C. in early 1993. The intended victim was walking down a city street with friends when a car pulled up and shots were fired at him. These examples illustrate exchanges between the judge and various of the witnesses which were fairly typical of judge-witness interchange during the course of the trial. ${ }^{6}$ ("THE COURT" refers to the Judge. "A" always indicates the answer provided by the witness, and " $Q$ " refers to questions directed by legal counsel):

\section{Excerpt 1}

Q:

Perhaps you could come down and point it out to the jurors closer to the jury so they can see that.

A: $\quad$ Right here, right in here.

THE COURT: Constable, could you speak up, please.

A: It's located where the white piece of paper is, yes.

\section{Excerpt 2}

MR. WILSON [Counsel for the defendant]:

All right. Thank you, constable, I have nothing

further. 
THE COURT: Miss Tomasson.

MS. TOMASSON [Counsel for the prosecution]:

Nothing arising, my lady.

THE COURT: Thank you, constable, you may be excused.

\section{Excerpt 3}

A: It wasn't all the way down to his shoulders, it was maybe like down here.

THE COURT: Mr. Martinez, I didn't hear your answer. Could you repeat that answer?

A: I say it wasn't all the way down to his shoulders, the hair is there.

\section{Excerpt 4}

MS. TOMASSON:

My lady, this witness will require the assistance of the interpreter, but he will be speaking in Spanish, so if there's any difficulty the accused will be able to understand it. Perhaps we could go through that again.

THE COURT: Yes, sir. Please have a seat. I understand you are going to give your evidence in Spanish?

A: Yes.

\section{Excerpt 5}

Q: $\quad$ How old are you Mr. Bardales?

A: $\quad$ Twelve years old.

Q: What is your birth date?

A: $\quad$ August 3rd, 1980.

MR. WILSON: Okay. Would you answer the questions the Judge has for you, please.

THE COURT: Mr. Bardales, when did come [sic] to Canada?

A: When?

THE COURT: Yes.

A: I was too small. I can't really remember.

THE COURT: So you have been here for a number of years, have you?

A: Yes. 
THE COURT: Do you go to school in Vancouver?

A: Yes.

THE COURT: Where do you go to school?

A: In Carlton.

THE COURT: In Carlton. What grade are you in -

A: $\quad$ Six.

THE COURT: - at the moment? Grade 6 . Have you ever been in the courthouse before, Mr. Bardales?

A: No.

As noted above, Brown and Levinson's politeness model predicts the use of "bald on record" language by the judge in all circumstances. That linguistic strategy would also be appropriate in light of the judge's function in running the court. Instead, each of these excerpts demonstrates the judge's use of negative politeness strategies towards the witnesses. Three negative politeness strategies are evident here - "Be conventionally indirect," (Strategy 1), "Question, or Hedge" (Strategy 2), and "Give Deference" (Strategy 5). In the first strategy, being conventionally indirect, a speaker can choose to perform an FTA on record by using the indirectness to mitigate his or her action. This is evident in the phraseology used by the judge in the first four extracts ("Could you speak up please?" [1]; "You may be excused." [2]; "Could you repeat that answer?" [3]; and "Please have a seat. I understand that you are going to give your evidence in Spanish?" [4]). And, by framing her speech in the form of a question (Strategy 2) in extracts 1,3, and 4 , the judge further disarms the implicit face threat posed by her request by avoiding a too-direct assumption about the hearer. Offering deference (Strategy 5) permits a speaker to mitigate his or her performance of an FTA by either humbling himself or herself, or by raising the status of the hearer. In this regard, we can see that the judge in each instance employs a specific form of deferential address ("Constable" [1 and 2]; "Mr. Martinez" [3]; "Sir" [4]), as well as a polite "Please" or "Thank you," which also act to soften the face threat. Even in the last excerpt, with the twelve-year-old child, Carlos Bardales, the judge chooses to redress her rather direct questions by periodically addressing him as "Mr. Bardales." In all of these cases, the effect of the judge's strategy is to exhibit respect behavior towards the witness and to maintain social distance.

However, the use of negative politeness strategies by the judge in these instances appears to represent a linguistic contradiction. The negative 
politeness strategies discussed above normally provide a way for a speaker to recognize the hearer's face by suggesting that the speaker will not interfere with the hearer's freedom of action. But the judge's role in the courtroom gives her the power to dictate the activities of all of the other parties, and both her role and the politeness model predict she will use an efficient, clear, and direct manner, which presents an inherent threat to the hearer's face. The judge's role and her choice of a negative politeness strategy thus seem to contradict one another, and also to contravene Brown and Levinson's rule that the politeness strategy chosen should never "[afford] more opportunity for face-risk minimization than is actually required to retain cooperation" (p. 74).

The solution to this contradiction is to be found in the dual-purpose nature of the negative politeness strategy. Brown and Levinson state that negative politeness provides “a purely conventional 'out' [that] works as redressive action...because it pays a token bow to the negative face wants of the addressee. [The speaker can give] conventional 'outs', that is, pretend to offer an escape route without really doing so, thereby indicating that he has the other person's face wants in mind" (pp. 71-2). In this sense, the negative politeness strategy has the effect of "permitting [the hearer] to feel that his response is not coerced" (p. 70). In the circumstances of the courtroom, it is obvious that the judge does not really intend to offer the witnesses a choice in responding to her requests. But her use of negative politeness, in offering an apparent alternative rather than a real alternative, acts to observe the witnesses' face needs, while simultaneously enabling the judge to carry out her function. By allowing the witnesses to feel that they are not being coerced, negative politeness serves to create the impression that the circumstances are not coercive, that it is really a cooperative talkexchange which is taking place. Such an approach recognizes that, ultimately, one cannot coerce real cooperation; but by creating an apparent atmosphere of cooperation - a symbolic cooperation - negative politeness achieves precisely the judge's purpose: obtaining the witnesses' information and maintaining the smooth operation of the court.

\section{Lawyer-Witness Interaction}

We see a similar process taking place in an extended excerpt from the same trial, featuring another more powerful/less powerful interaction, this time between a lawyer and a prosecution witness. In this instance, the intended victim is being cross-examined by the defense lawyer about 
incidents leading up to the murder attempt:

MR. WILSON:

Q:

A:

Q:

A:

Q:

A:

Q:

A:

Q:

A:

Q:

A:

Q:

A:

Q:

A:

Q:

A:

Q:

A:

Q:

A:

Q:

A:

Q:

A:

Q:

A:
Do you know a person by the name of Marty Eng? No.

No?

No I don't know.

You don't?

That name sounds familiar.

Sorry?

I sort of remember that name.

Okay. Well, do you know Marsella West?

Yes.

She's your girlfriend?

Right.

Right?

Yes.

Marty Eng is a pimp. Do you know him?

Yeah.

Yeah. You took a girl away from him, right?

No.

No?

No.

Marsella used to know him?

Yes.

All right. Isn't it true that early last year Marty Eng came over and burned Marsella's face with a cigarette; is that true?

I wasn't there.

Isn't it the case that he threatened you?

No.

No?

No. (p. 48)

One of the notable aspects about the interchange between this lawyer and this witness is the lawyer's persistent use of repetition: a tactic of repeating the witness' answer back to him before continuing with the questioning process. (In the interests of brevity, I am focussing on just one technique of many which lawyers might use.) How does this lawyer's use 
of cross-examination strategy fit into the repertoire of politeness strategies? Brown and Levinson's taxonomy describes repetition as one of the strategies of positive politeness: a speaker does an FTA on record with redress in order to claim common ground (see Figure 2). Specifically, repetition can be used to take notice of the hearer (Strategy 1) by demonstrating that the speaker has heard the hearer's words correctly.

However, this strategy does not seem appropriate to the function of cross-examination, which requires a lawyer to test a witness' credibility. Once again, we observe a linguistic contradiction - the function of crossexamination requires that the lawyer threaten the witness' face, but instead he chooses a politeness strategy which preserves the witness' face. As in the case of the judge, the lawyer's role and his politeness strategy seem to be at cross-purposes. To negotiate this complex situation, the lawyer, like the judge, has chosen a politeness strategy - do the FTA off record - which permits him to fulfill both needs (Strategy 4) (see Figure 3). Off record communication gives the speaker an "out" by providing a number of defensible interpretations for the speaker's words. In this way the speaker can perform an FTA and avoid responsibility for it, leaving the hearer or hearers to decide how to interpret it by making an inference.

Off record communication involves a two-stage process: first, a trigger is required to serve notice that some inference must be made; second, a mode of inference derives what is meant from what is actually said. In these excerpts, the lawyer is likely not using repetition so many times in order to show that he has heard the witness' words correctly, as positive politeness would suggest. It is more likely that the lawyer intends the exact opposite indicating his disagreement with the answer. ${ }^{7}$ Using language to convey the opposite meaning of what is stated involves the use of the off record strategy, "Be ironic" (Strategy 8). The violation of Grice's Maxim of Quality, "Be sincere," is the trigger. The function of cross-examination and the determined use of this tactic by this lawyer provide the contextual clues that an inference should be drawn. ${ }^{8}$ And the inference available to be drawn by the hearers, should they choose to, is that the lawyer is not in agreement with the witness' answer, and that the witness therefore lacks credibility thereby achieving precisely the purpose of the cross-examination.

\section{Discussion}

The above analyses of the judge-witness and lawyer-witness interaction confirm Cashion's discovery of unexpected politeness strategy selections 
by courtroom speakers contrary to Brown and Levinson's predictions. Why does Brown and Levinson's purportedly universal model not work in these examples as expected? Despite the politeness model's remarkable contribution to discourse studies since its inception in the late seventies, other researchers - and, indeed, Brown and Levinson themselves - have uncovered a number of problems with the model, with general agreement that it underrates the complexity of social processes which affect and are affected by communication (e.g. Kaspar, 1990; Coupland et al., 1988; Tracy, $1990 \mathrm{~b})$. This is particularly true of a context such as a courtroom, the institutional nature of which adds an extra dimension to interpersonal interaction. Analysis of communication in a courtroom context requires the analyst to consider the effect of this institutional dimension on the politeness strategies selected by the speakers. To illustrate this, I will discuss below additional considerations - the increased complexity of the speaker's and hearer's roles and face-needs - which derive from the institutional context and which affect the model's operation as an alytical tool.

\section{Institutional Dimension of the Speaker}

The institutional dimension of a courtroom context renders the concept of the speaker more complex than Brown and Levinson allow for. While the Brown and Levinson speaker is an abstract Model Person, a "cardboard figure" engaged in universalized interpersonal relations which are bereft of any significant context (p. 58), the courtroom context adds a particular institutional role as an aspect of the speaker's identity, a role which the speaker inhabits and which is oriented towards achieving a particular institutional task. In our sample analyses above, the speaker's interpersonal exchanges are affected by her or his role as a judge or a lawyer and the need to accomplish the respective tasks of administering the court or of skilful cross-examination. The speaker's identity is thus compounded of an institutional aspect as well as an interpersonal aspect.

Part of the impact of institutional role is evident in the manner in which the institutional speakers in the above analyses seem to subordinate their politeness strategies vis-à-vis the witnesses to the accomplishment of their institutional task. That a task and face action are carried out simultaneously is not unusual; indeed, other researchers have argued that "language is multifunctional, serving other purposes besides facework" (Tracy, 1990b, p. 222), and that social interaction should be characterized as motivated by multiple goals (Tracy, 1990a). However, the courtroom analyses 
above appear to follow Christine Iacobucci's (1990) work on simultaneous task and facework goals in customer service encounters, which concluded that nominally relation- or facework-oriented talk is not always indicative of a relational goal, but can be used as a strategy to achieve a task-goal: “The important point here is that... ostensibly relational talk may have a use, a purpose, for accomplishing a task-goal" (p. 97). The need to simultaneously accomplish a task that is role-related in addition to an interpersonal goal, however, is not a factor included within the P, D, R analysis of Brown and Levinson.

Another aspect of institutional role which has an impact on interpersonal dynamics is the significance of speaker face for those inhabiting institutional roles. Hymes (1986) and other critics (e.g. Penman, 1990; Craig, Tracy, and Spisak, 1986) have pointed out that while Brown and Levinson discuss both speaker and hearer face in their framework and argue the importance of cooperation in maintaining each other's face, too often their "specific explanations...come down to the 'rhetorical' function of effect on others alone, neglecting...concern for the speaker's negative and positive face," particularly "what may be proper or required because of a speaker's position or personal style" (p. 81). Penman (1990) attempted to remedy this omission in the politeness model by incorporating both self and other face dimensions in her own revised typology of facework. While Brown and Levinson's model does not extensively explore the importance of the speaker's face as a factor in facework analyses, sociologist Pierre Bourdieu delineates its particular importance within an institutional setting.

Bourdieu $(1977,1991)$ looks at language not from the perspective of politeness strategies but from an economic model of linguistic exchange in which language constitutes "symbolic capital" which is inseparably linked with the speaker's position in the social structure (1977, p. 646). For Bourdieu, language is never mere communication alone; it is always also an economic exchange within "a particular symbolic relation of power between a producer, endowed with a certain linguistic capital, and a consumer (or a market), and which is capable of procuring a certain material or symbolic profit" (1991, p. 66). The language of those in authority (for our purposes, those in institutional roles) "has to contribute to its own credibility" (1977, p. 649), Bourdieu claims, and one of the ways of doing so is what he calls the "strategy of condescension" which "consists in deriving profit from the objective relation of power between the languages that confront one another in practice... in the very act of symbolically negating 
the relation" (1991, p. 68). This strategy can be used when the "objective disparity" between the social properties of the speaker and the hearer is obvious to all involved. In these cases, "symbolic negation of the hierarchy...enables the speaker to combine the profits linked to the undiminished hierarchy with those derived from the distinctly symbolic negation of the hierarchy - not the least of which is the strengthening of the hierarchy implied by the recognition accorded to the way of using the hierarchical relation" (1991, p. 68).

Bourdieu's claim that authorities use language to bolster their credibility is apparent in the strategies which the judge and lawyer employ in the sample analyses. The judge and lawyer are established in an asymmetric symbolic power relation with the witnesses as a result of the power hierarchy in the courtroom and the institutional authority which backs it. They are sufficiently removed from the social rank of the witnesses, and sufficiently confident of their position in the hierarchy, "to be able to deny them without appearing to be ignorant" (1991, p. 69). The obvious disparity within the courtroom between their social properties and those of the witnesses permits them to "profit" doubly, both as a result of their original position (high in the power hierarchy) and as a result of their "symbolic negation" of that hierarchy. Thus, their exercise of politeness strategies towards the witnesses, while appearing to recognize the witnesses' face to a greater extent than necessary, and, consequently, to threaten their own face, actually serves, as Bourdieu suggests, to strengthen the disparity between their hierarchical positions and to enhance their own (institutional) face.

The importance of contributing to the credibility and face of an institutional role is especially necessary in light of the presence of coercion in the context. Coupland et al. (1988) have illustrated this by using as an example another institutional setting - a hospital - in which nurses are required to administer medicine to unwilling elderly patients. In the course of these duties, they employ positive politeness strategies with the patients. Coupland et al., who have also called for deeper and more elaborate analyses of facework (p. 261), suggest that in such a situation a simple P, D, R analysis would be naive in concluding that the nurses used positive politeness strategies in order to redress the FTA created by their conduct. Deeper scrutiny, they contend, reveals that the principal FTA is not the verbal act of requesting, but the fact of coercion in the task of administering the medicine, which mere verbal politeness is unlikely to redress. In the eyes of Coupland et al. the interpersonal relationships in this situation are less 
significant than the institutional roles which the participants inhabit and their function of carrying out an institutional task, and the real redress being carried out is redress of the threat to the nurses' and the institution's faces, since "[i]n a public (at least multiparticipant) context, and probably in its own right, coercion is indeed face-threatening to coercer and coerced" (p. 260). From their perspective, the politeness strategy which is chosen by the nurses functions primarily as "own- (own-group) faceredress," rather than the recipient-face-redress which it purports to be (p. 260). This more complex analysis insists that "facework strategies need to be seen as nested or hierarchical, a strategy at the (apparently) interpersonal level serving a higher-order strategic purpose" (p. 261). ${ }^{9}$

Obvious parallels can be perceived between Coupland et al.'s hospital illustration and the courtroom. A coercive context is indeed created by the powerful institutional framework of the court and it is this which constitutes the main FTA for witnesses. The need to carry out an institutional task within this environment simultaneously threatens the face of the actors whose institutional roles as judge and lawyer dominate interpersonal relations. And dual-purpose face strategies are used which simultaneously have both apparent and real aspects, comprising a "nested or hierarchical" strategy directed to a "higher-order strategic purpose." That politeness functions here as "own- (own-group) face-redress" simultaneously with purported other-redress is directly connected to the accomplishment of an institutional task in a coercive context: part of getting a task done within an institutional environment must be "own- (own-group) face-redress"; otherwise, the integrity of the institutional system could be impaired. At the same time, purported other-face redress acts to soften the coercion, permitting institutional authorities to paradoxically coerce participants to "cooperate." The apparent strategy (and the coercive framework) gain the cooperation, while the real strategy serves to maintain institutional face.

\section{Institutional Dimension of the Hearer}

The greater complexity inherent in an institutional setting is not limited to the speaker role; it is also apparent in the conceptualization of the hearer and in the hearer's face-needs. While Brown and Levinson largely conceived of discourse as dyadic, the public nature of an institutional context and the presence of multiple participants again adds an additional dimension to conversation. What is the effect of the fact that other parties are privy to the talk that takes place between the witnesses and their institutional 
interlocutors, the judge and the lawyer? The effect of multiple participants on discourse has been thoroughly examined by Clark and Carlson (1982) who have argued that a speaker's utterance is influenced by both addressees as well as others, whom they term side-participants and overhearers. As they point out, when a lawyer asks a defendant addressee a question, "if this is to count as an official question...then he must also be informing the judge, jury, and other court officials that he is asking the defendant that question" (p. 340). Clark and Carlson argue that the basic design of an utterance is directed to participants, in which category they include all of those who are intended to take part in the utterance, whether directly addressed or not. The actual addressee of the utterance and overhearers of the utterance are taken care of in modulations on the basic design. Speakers "assign different hearers to different roles; and then they decide how to say what they say on the basis of what they know, believe, and suppose that these hearers, in their assigned roles, know, believe, and suppose" (p. 342). In a public context such as a courtroom, there is increased complexity because of the various layers of parties who may "take part" - the judge, the jury, lawyers, witnesses, courtroom staff, the media, the general public, etc. Although Clark and Carlson do not specifically consider politeness strategies in their argument, it seems a logical extension of their theory to assume that the presence of multiple hearers will also affect a speaker's choice of politeness strategies so as to observe the face-needs of all participants. And at least one recent study has documented the effect of bystanders on discourse style, asserting that a powerful side-participant may be as important as an addressee in shaping politeness strategies (Aronsson and Rundstrom, 1989).

\section{Conclusion}

While the politeness model relies on a simple determination of the relative relationship between speaker and hearer, I have attempted to show that those roles have, in the courtroom and in other institutional contexts, more than a singular aspect. The judge in the example above speaks to the witnesses not only in her individual capacity but as the representative of a group or institution, as the wielder of institutional power within a coercive process. Hers is a multi-faceted role and in her speech "what speaks is not the utterance... but the whole social person" (Bourdieu, 1977, p. 653). Likewise the lawyer's interchange with the witness reflects more than just an interpersonal relation - it is primarily embedded in an institutional role 
which is focussed on accomplishing a task above all. The complexity of the hearer role is also evident in the public multi-participant context in which the judge and lawyer speak - the "double frame" of listeners which I earlier postulated. For the judge, this broader secondary audience extended beyond the witness to include the jury, the lawyers, others present in the courtroom, and the broader public context outside of the courtroom which bases its understanding and support of the legal system on what takes place in court. For the lawyer, beyond the witness was the judge and jury who drew the inferences which evaluated the credibility of the witness and his testimony in the overall case.

Ultimately, it is the combined complexity of the speaker and hearer roles in this instance that leads to the unexpected functioning of the politeness model and the judge's and lawyer's choice of a multi-purpose strategy. For this multi-purpose strategy serves complex face-needs. On the one hand, the use of politeness by a person of substantial institutional power recognizes not only the witness' face, but also that of the broader social milieu. It recognizes that in Canada a witness has the right to the liberty of his or her person and that that right is impeded by the coercive processes of the courts, a social result which demands a calculated linguistic response. On the other hand, the judge's and lawyer's choice of a multi-purpose facework strategy acts as a "nested or hierarchical" move, with the strategy at the apparently interpersonal level serving another higher-order strategic purpose: while it purports to be recipient face redress, it primarily functions as "own- (own-group) face-redress," as enacted by Bourdieu's strategy of condescension.

In these example analyses, we have seen institutional actors using multipurpose strategies which allow them to negotiate the multiple dimensions both interpersonal and institutional - of the courtroom. These strategies also allow these actors to negotiate the contradictions between the goals of cooperation and coercion which "tension" interaction in this setting (Tracy, 1990 a, p. 8) and which must be worked out in actual behaviour. But the factors discussed here are not limited to the courtroom - they are applicable to institutional and organizational contexts generally. The concepts of institutional role, task goals, and institutional or group face, and the presence of multiple participants are relevant to many types of workplace, to corporate and organizational contexts, and to public and official situations. To face the complexity of human interaction in these institutional contexts requires 
a move beyond a traditional approach based in the certainty and singularity of meaning; it requires instead that one assume that meaning is inherently problematic and manifold, complex and uncertain like reality (Penman, 1990, p. 37). All of these factors go beyond the supposed rational model of courtroom discourse which seems so parallel to Grice, and beyond Brown and Levinson too. Legal discourse - and all discourse — is, indeed, a very social phenomenon.

\section{Notes}

1. The author wishes to thank A. Lynne Magnusson for her invaluable comments on earlier versions of this paper, which was developed out of a graduate seminar held at the University of Waterloo in the summer of 1993. Thanks are also due to two external reviewers who read the paper and whose suggestions contributed greatly to its improvement. An earlier version of the paper was presented as part of the "Technical Communication in Cross-Cultural Contexts" theme at the Canadian Association of Teachers of Technical Writing annual convention during the Learned Societies Conference/Congrès des sociétés savantes held at Montreal, Quebec, MayJune 1995.

2. Little (1979) and Cashion (1985) have both drawn on the politeness model to confirm the presence of politeness in the courtroom, but neither attempted a complete application of the model or designed their studies to fully assess it. Little used the link which Brown and Levinson established between face and politeness to question the presence of coercion and politeness together in the courtroom, particularly in the examination of witnesses. She considered overt displays of deference, such as the use of "please," "thank you," and indirect requests, as indicators of politeness, but did not distinguish them further on the basis of either Brown and Levinson's five main strategies or their specific sub-strategies. Cashion's analytical approach was based on Shimanoff (1977) which coded only negative and positive politeness, thus using only a portion of the range of strategies identified by Brown and Levinson for handling FTA's.

3. Despite Cashion's limited use of the politeness model (as described above), her results still serve to demonstrate that the selection of politeness strategies in the courtroom does not follow the predictions of the politeness model. For example, the judges in Cashion's study regularly employed both negative and positive politeness, when according to Brown and Levinson's hierarchy of strategies the contrary should have been the case - the judges should have eschewed both negative and positive politeness in favour of a "bald on record without redress" approach. Cashion attempted to explain this by hypothesizing that the judges employed unexpected politeness in order to manifest their power (their ability to choose how they spoke); however, the politeness model would call for such a manifestation to be enacted through a lack of politeness or redress altogether.

4. Little (1979) also observes that "[courtroom questioning] differs from ordinary conversation greatly because the information is not for the benefit of a questioner but for a third party - the decision-maker or jury" (p. 360). 
5. The author wishes to express thanks to Jill Tomasson Goodwin for having drawn the transcript of this trial to her attention.

6. Recognizing that the multiplicity and variability of trial discourse cannot be captured in one set of texts, I do not intend in this paper to argue that all judges consistently speak in this manner, and its typicality warrants further research. The use of negative politeness in this transcript is, however, supported by the results of Cashion's (1985) study, which noted significant use of negative politeness by judges based on her analysis of six civil trial transcripts, as well as by my personal experience as a lawyer. Cashion comments in her concluding remarks that "although judges use a great deal of politeness in the course of conducting court proceedings, this is not to say that they cannot be direct, go "bald on record"... with their requests" (18).

I also wish to note that while the judge who presided over this trial was female, I have not considered sex as a factor affecting politeness usage following Cashion (1985) who compared the politeness usage of an equal number of male and female judges and concluded that the sex of the speaker did not appear to influence the amount of politeness used (p. 15).

7. A related observation was made by Little (1979) in her study of questions during witness examination: "Politeness on cross examination is usually a precursor of challenge or conflict" (p. 364). During cross examination "a lawyer can use politeness to mislead or confuse a witness while he gives the superficial appearance of being solicitous" (p. 367).

8. Robyn Penman comments on the difficulties of interpreting facework when utterances can be multi-functional, so that different strategies can be expressed simultaneously in the same utterance or sequentially. In the latter case, Penman observes:

This...well illustrates the problems of inferring facework. If the dialogue was taken only one step at a time, it would either appear as commonplace or nonsensical...Sense is made of the ensuing exchange only after the episode is ended. It is by moving backward through the retrospective context, that it is possible to develop a coherent account for the exchange as a whole. (1990,33)

To cope with this complexity, Penman has developed a more elaborated politeness typology which includes categories for both self-directed positive or negative facework and other-directed positive or negative facework, and which delineates degrees of facework micro-strategies as either mitigate/enhance, protect, threaten, or aggravate/depreciate.

9. In another article, Coupland, Coupland, Giles, and Henwood (1991) distinguish three possible levels of goals: at the lowest level, goals formulated in relation to individual speech acts or moves; at a higher level, goals for whole social episodes and encounters; and, at the highest level, goals which concern "more enduring socio-emotional needs and priorities." Coupland et al. suggest that goal multiplicity is an inevitable aspect of talk and, following Hawkins and Daly (1988), argue for a hierarchical arrangement of goals, "with the highest level goals often exerting influence over - or, at least, providing a context for - lower level goals 'nested' within them." Local goals may also influence high-level goals by "triggering or making salient" high-level goals (p. 82). 


\section{References}

Aronsson, K., \& Rundstrom, B. (1989). Cats, dogs, and sweets in the clinical negotiation of reality: On politeness and coherence in pediatric discourse. Language in Society, 18, 483-504.

Atkinson, J. M., and Drew, P. (1979). Order in court. London: Macmillan.

Bourdieu, P. (1977). The economics of linguistic exchanges. Soc Sci Inform, $16,645-668$.

(1991). Language and symbolic power. J. B. Thompson (Ed. and Intro.), Cambridge: Polity Press.

Brown, P., \& Levinson, S. C. (1987). Politeness: Some universals in language usage. Cambridge: Cambridge University Press.

Cashion, J. L. (1985). Politeness in courtroom language. Washington, D.C.: ERIC (ERIC Document Reproduction Service), No. ED 254882.

Clark, H. H., \& Carlson, T.B. (1982). Hearers and speech acts. Language, 58, 332-373.

Coupland, N.,Grainger, K., \& Coupland, J. (1988). Politeness in context: Intergenerational issues. Language in Society, 17, 253-262.

Coupland, N., Coupland, J., Giles, H., \& Henwood, K. (1991). Intergenerational talk: Goal consonance and intergroup dissonance. In $\mathrm{K}$. Tracy (Ed.), Understanding face-to-face interaction: Issues linking goals and discourse, (pp. 79-100). Hillsdale, New Jersey: Lawrence Erlbaum Associates.

Craig, R. T., Tracy, K., \& Spisak, F. (1986). The discourse of requests:

Assessment of a politeness approach. Human Communication Research, 12, 437-68.

Fisher, S. (1984). Institutional authority and the structure of discourse.

Discourse Processes, 7, 201-224.

Goffman, E. (1967). Interaction ritual: Essays on face to face behavior. Garden City, New York.

Grice, H. P. (1975). Logic and conversation. In P. Cole \& J. L. Morgan (Eds.), Syntax and semantics, Volume 3: Speech acts, (pp. 41-58). New York: Academic. 
Hawkins, R. P., \& Daly, J. (1988). Cognition and communication. In R. P. Hawkins, J. M. Wiemann, \& S. Pingree (Eds.), Advancing communication science: Merging mass and interpersonal processes, (pp. 191-223). Newbury Park: Sage.

Hymes, D. H. (1986). Discourse: Scope without depth. International Journal of the Sociology of Language, 57, 49-89.

Iacobucci, C. (1990). Accounts, formulations and goal attainment strategies in service encounters. In K. Tracy \& N. Coupland (Eds.), Multiple goals in discourse, (pp. 85-99). Clevedon: Multilingual Matters.

Kasper, G. (1990). Linguistic politeness: Current research issues. Journal of Pragmatics, 14, 193-218.

Little, G. (1979). Politeness in the courtroom. In W. Wolck \& P. Garvin (Eds.), Fifth LACUS Forum, (pp. 289-97). Columbia: Hornbeam Press.

Penman, R. (1987a). Discourse in courts: Cooperation, coercion, $\&$ Coherence. Discourse Processes, 10, 201-218. (1987b). Regulation of discourse in the adversary trial. Windsor Yearbook of Access to Justice, 7, 3-20.

(1990). Facework and politeness: Multiple goals in courtroom discourse. In K. Tracy and N. Coupland (Eds.), Multiple goals in discourse, (pp. 15-38). Clevedon: Multilingual Matters.

Regina v. Bardales. January 11-19, 1993. Unreported decision of the Supreme Court of British Columbia.

Shimanoff, S. (1977). Investigating politeness. In E. O. Keenan and T. L. Bennett (Eds.), Discourses across time and space, (pp. 213-241). Los Angeles: University of Southern California.

Tracy, K. (1990a). Multiple goals in discourse: An overview of issues. In K. Tracy and N. Coupland (Eds.), Multiple goals in discourse, (pp. 1-13). Clevedon: Multilingual Matters.

- (1990b). The many faces of facework. In H. Giles and W. P.

Robinson (Eds.), Handbook of language and social psychology, (pp. 209-226).

Chichester: John Wiley and Sons. 